\title{
The Socioeconomic and Environmental Effects of Sustainable Development in the Eastern Carpathians, and Protecting its Environment
}

\author{
Jaroslav Solár*, Marián Janiga, Katarína Markuljaková \\ Institute of High Mountain Biology, University of Zilina, \\ Tatranská Javorina 7, SK-059 56 Slovak Republic
}

Received: 16 March 2015

Accepted: 13 October 2015

\begin{abstract}
The rich cultural heritage of its Ruthenian and Ukrainian minorities and preserved natural ecosystems represent potential for the development of sustainable forms of tourism in the region of Poloniny National Park in the Eastern Carpathian Mountains. Social and political changes in the region during the $20^{\text {th }}$ century led to land abandonment, emigration of young generations, and reforestation. Some socio-economic relationships clearly reflect global trends at the regional level. At the local level, we found a weak relationship between socio-economic parameters and the system of protecting the environment. If environmental protection is increasingly marginalized in the future, this may lead to the enduring perception among the inhabitants that it is unnecessary. Therefore, local inhabitants should be engaged in activities and cooperate with nature conservation bodies to improve and create new economic opportunities founded on nature-based tourism, which should not have an intense negative impact on the country and its values.
\end{abstract}

Keywords: Carpathian Mountains, demography, economy, land use, nature protection, Poloniny NP

\section{Introduction}

The Eastern Carpathian Mountains surrounding the triborder of Slovakia, Poland, and Ukraine are populated by a mixture of ethnic groups including Slovaks, Ukrainians, Poles, Jews, and Gypsies, but it was the Wallachian colonization in the $15^{\text {th }}$ and $16^{\text {th }}$ centuries by shepherds and peasants known as Ruthenians (Russians) that most influenced the development of the landscape and greatly affected forests in the region $[1,2]$. Agriculture was a traditional way of life in villages in the Bukovské

*e-mail: solar@uniza.sk vrchy Mts. for centuries. Long-term utilization of mountain meadows and pastures led to the development of unique, species-rich mountain plant communities [3]. Collaterally with the Wallachian colonization, the first mountain meadows, known as poloniny, emerged. The word polonina, of Ruthenian-Ukrainian origin, refers to semi-natural grassland formations above the timber line [1]. The poloniny grasslands are valuable from a nature conservation perspective due to their biodiversity $[4,5]$. However, they are not the only outstanding natural asset in the Eastern Carpathians. Despite continuous exploitation of the region since the $14^{\text {th }}$ century, some forest stands in less inaccessible areas have preserved their primeval character [6]. The richest beech forests are in Ukraine, 
including Subcarpathian Rus [7], but there are also several substantial fragments of virgin forest in Slovakia: Stužica, Havešová, Riabia skala, Rožok, and Udava [8]. They are unique examples of the development of terrestrial ecosystems and communities in the Holocene. Carpathian beech forests represent a globally significant natural gene bank of beech and associated species [9].

At the time of the first Czechoslovak Republic (191838 ), the region of Poloniny was one of its least developed areas. In the $20^{\text {th }}$ century this territory was witness to three wars: World War I, the Slovak-Hungarian or "Little" War in 1939, and World War II [2]. This brought degradation of living conditions for the local people. As a result of the Little War, part of Poloniny was ceded to Hungary, leading to significant deforestation. The remaining virgin forest, mainly in Stužica, was saved from logging by the termination of World War II and the rearrangement of national borders, under which Transcarpathia became part of the Soviet Union (now Ukraine). This made access and economic use of land from the Slovak side very difficult [8].

Since World War II there have been three key policyinduced milestones of agricultural change in mountain regions $[10,11]$ : collectivization, a shift from central (state) planning to a market economy, and membership in the European Union. Societal change and economic development in Slovakia from 1948 to 1989 had significant influence on agricultural trends in the Poloniny region. Intensification took place - especially in lowlands, mountain valleys, and slopes around villages, where farm machinery had better access [12]. Collectivization (197089) led to a change of employment type from full-time farmers to hobby farmers. Many farmers were forced to commute to work in nearby urban centers with expanding industries [12]. The construction of Starina Reservoir also had a radical impact on the region in addition to postwar reconstruction and socialist construction in the 1980s. Seven municipalities with a total of 3,500 inhabitants were evicted to facilitate the reservoir's construction [2].

The region has therefore seen a continuous population decrease since World War II up to the present time [12]. Currently, it is among the most sparsely populated and least developed regions of Slovakia. Its peripheral position, lying outside the routes of Pan-European multimodal transport corridors [13], a closed valley, population displacement, gradual abandonment of farming, economic recession, and changing lifestyles of young generations, as well as marginalization and backwardness (underdevelopment) have had significant effects on communities in the region, where use of the surrounding landscape has been predominantly agroforestry [14]. Negative socio-economic development has contributed to the preservation of some habitats and rewilding of landscapes. For example, following the end of World War II, inhabitants of the Polish side of the Bukovské vrchy Mts. were displaced/resettled for military reasons [3]. Significant depopulation since the 1960s and 1970s was due to collectivization. Such social and political changes led to a state of gradual neglect and abandonment of meadows, accelerating the process of secondary succession, in growth, and reforestation [3, 4, 15]. Poor technical infrastructure, marginal location, and deficient employment opportunities led to land abandonment and emigration [16], especially of the younger generation. The aging population is gradually retreating from land-use management (farming), particularly at higher elevations.

The rich cultural heritage of Ruthenian and Ukrainian minorities [2] and the preserved ecosystems of natural beech forests and species-rich, semi-natural grasslands [4, 5] represent great potential for development of sustainable forms of tourism. The beginnings of regional (territorial) protection in the Eastern Carpathians date back to the $17^{\text {th }}$ century. The first written record of a 'protected oak grove' with no timber harvesting is from the village of Stakčín in 1660 [2]. Protection of rare beech forest complexes began in the 1970s with the establishment of Bieszczady National Park (1973) in Poland and the Eastern Carpathians Protected Landscape Area (1977) in Slovakia [17, 18]. In 1992 these two areas were designated a Transboundary Biosphere Reserve within UNESCO's Man and the Biosphere (MAB) Programme [19]. Poloniny National Park was established in Slovakia in 1997 [20], and in 1998 the world's first trilateral Biosphere Reserve (BR) was established comprising Poloniny NP, Bieszczady NP, and Uzhanski National Nature Park in Ukraine [21]. In the same year, Poloniny NP received the prestigious Council of Europe's European Diploma of Protected Areas that is awarded to areas of outstanding scientific, cultural, or aesthetic qualities that are the subject of a suitable conservation scheme.

The situation in the Eastern Carpathians reflects present global trends resulting from pervasive socio-economic driving forces leading to spontaneous reforestation of abandoned mountain landscapes in Europe [22-25], which may represent a growing threat to biodiversity. Rural depopulation, land abandonment, and scrubbing over of the landscape has accelerated and consolidated in many mountain areas [26-29]. More broadly, land abandonment and rural depopulation $[30,27]$ represent the socioeconomic trend in Western Europe [31], whereas in Eastern Europe land abandonment was associated with the transition process [32]. Generally, three processes currently dominate in the region: forest expansion, urban sprawl [24], and rural depopulation. Recent socioeconomic trends in the whole trilateral region have led to increased forest fragmentation, more so in Slovakia and Ukraine than in Poland, mainly due to forest management [6]. Differences in disturbance rates among countries appear to be most closely related to broad-scale socioeconomic conditions, forest management practices, forest policies, and the strength of institutions [30, 33].

There has been much recent discussion on the issue of population migration and depopulation of mountain regions, but quantitative estimates of these trends in relation to environmental protection are lacking. The aim of this study is to determine trends in socio-economic relationships in relation to the natural environment and its protection by means of a mutual assessment of socio- 
economic parameters such as land use, demography, and economic revenues with data on nature protection.

\section{Materials and Methods}

The basic unit for assessing sustainable development is taken as the household. Therefore, a streamlined management of natural, cultural and economic resources and human potential at the local level is the key to ensuring sustainable development $[34,35]$. We chose the Cadastral area as basic spatial unit. Various statistical data (data from government and non-government organizations) was linked to cadastral areas, which represent units of human settlements. Study area include the cadastral areas, which extend to Poloniny NP and its buffer zone (Fig. 1). We selected four groups of data in statistical analysis: regional political geography, regional demography, nature protection geography, and local economy.

Regional political geography represents data on land use obtained from the Land Registry Portal of the Slovak Republic [36]. Land Registry records total urban area and rural area and also total agricultural land (area of arable land, permanent grassland, gardens, and orchards), forest land, water sources, built-up areas, courtyards, and other areas.

Regional demography includes key indicators of demography such as population size and density, age structure by category (0-14 year olds, women aged 15-54, men aged 15-59, women over 55, and men over 60 years old), natality, and mortality. Demographic data were obtained directly from local governments in individual cadastral areas for 2012 (by questionnaire). Additional demographic information such as economic activity of citizens, the number and proportion of those unemployed, economically active and inactive, as well as information on education were obtained from the censuses of population and housing by the Statistical Office in 2011 [37].

Nature protection geography consists of data on nature protection and various protected areas (e.g. national nature reserves, NATURA 2000 sites, Dark Sky Park, UNESCO World Heritage Site) and cultural sites (especially wooden churches). These data were obtained from the Slovak Heritage Office [38] and the state list of protected areas [39]. Poloniny National Park itself is around 28,458 ha and its buffer zone has an area of 10,633 ha. A total of 2,290 ha are included in nature reserves.

The local economy represents data on revenues from forestry, hunting, tourism, water management, and taxes.

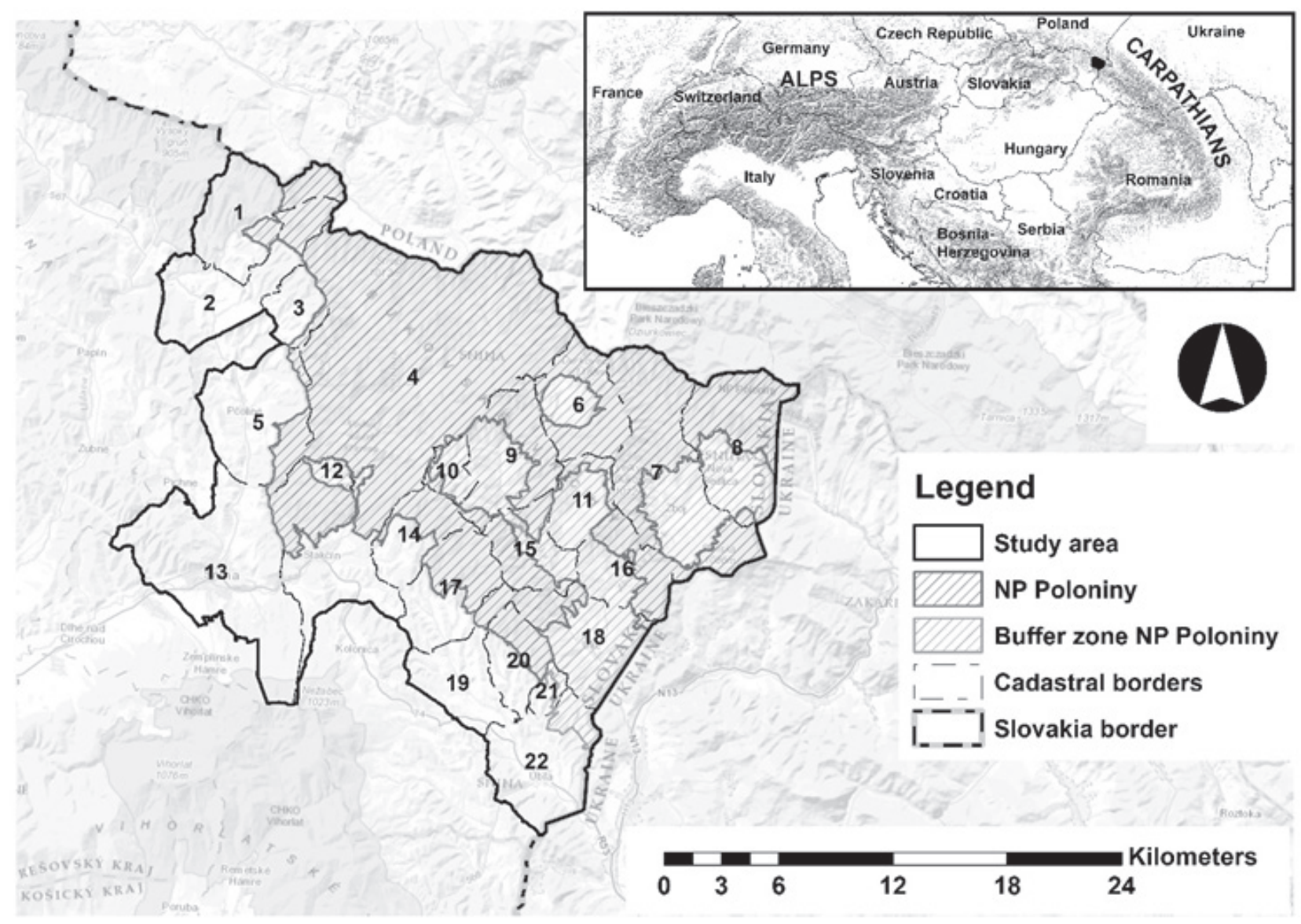

Fig. 1. Study area $\left(49^{\circ} 02^{\prime} 07.90^{\prime \prime N} ; 22^{\circ} 19^{\prime} 39.62^{\prime \prime} \mathrm{E}\right)$.

[1 - Osadné, 2 - Hostovice, 3 - Parihuzovce, 4 - Stakčín, 5 - Pčoliné, 6 - Runina, 7 - Zboj, 8 - Nová Sedlica, 9 -Topol’a, 10 - Príslop, 11 - Ruský Potok, 12 - Jalová, 13 - Snina, 14 - Stakčínska Roztoka, 15 - Kolbasov, 16 - Uličské Krivé, 17 - Kalná Roztoka, 18 - Ulič, 19 Klenová, 20 - Ruská Volová, 21 - Brezovec, 22 - Ubl'a] 
We selected industries whose revenues could be determined from the basic spatial unit (cadastre). Revenues from agriculture could not be identified, because agricultural land is managed by local forestry companies whose jurisdiction extends beyond cadastral boundaries. To calculate forestry revenues, we multiplied data on timber harvesting [40] by the average price of timber as specified by the state forests enterprise (timber harvesting in areas afflicted by a calamity was multiplied by the price of firewood). Hunting revenues are composed of membership fees, sales of game meat, hunting fees, and other revenues as listed in the hunting database of the National Forestry Centre for 2010 [41]. Tourism revenues represent revenues from accommodation and catering. The latter were calculated from the number of visitors to each settlement and a minimum price of $€ 3$ per person paid for lunch. To calculate accommodation revenues we used information on capacity and average prices in each community as found on the internet and a percentage usability coefficient. Data on capacity and visitor rates were obtained directly from local representative bodies/municipalities in individual cadastral areas (by questionnaire). Water management revenues were calculated for only a few villages with connections to the public water supply. Revenues represent the invoiced amount of drinking water at a price of $€ 1.57 / \mathrm{m}^{3}$. Data on revenues $\mathrm{f}$ rom shared taxes (such as local taxes and local fees, taxes for accommodation, rent of buildings, and municipal waste and taxes on forest and agricultural land) were obtained from local representative bodies.

We used these data to compile a matrix that was standardized and statistically analyzed. A principal component analysis (PCA) correlation matrix (a multivariate technique) was used to extract potential relationships between variables. Principal components are linear combinations of original variables; each axis is statistically orthogonal to the other. Integration of the variables enabled us to follow different phenomena more or less dependent on each other. We used several variables and evaluated seven principal phenomena in the Poloniny region (see results, Tables 1 and 2).

\section{Results}

The most important set of relationships in the area of Poloniny NP (explaining $42 \%$ of the total variance of the data) is the phenomenon of population concentration in cities and larger towns (PC1). The urban centers of Snina and Stakčín have greater proportions of young people and higher population growth than rural communities. Revenues in urban areas are obtained mostly from taxes, payment for water resources, and tourism. Revenues in rural settlements, with a greater proportion of seniors and lower population growth, are mainly from forestry. The proportion of protected areas and the existence of environmental protection were not related to this phenomenon (i.e., the State Nature Conservancy does not affect the demographic processes in the landscape, either negatively or positively).
Activities in the rural landscape (PC2, 18\% of total variance) are characterized by land use in rural areas and forest management. Revenues from rural areas are mainly from forestry activities, while there are lower revenues from taxes or tourism. This phenomenon is independent of demography and the proportion of the population that is economically active. The study site and the existence of the national park are dependent on land in rural areas, especially forest land. On the other hand, the size and location of national nature reserves (NPR) and nature reserves (PR) are independent of size or locations of rural areas. Generally, the overlap of protected land, forest, and agricultural land in relation to land use change creates a risk of harm to protected areas.

The next phenomenon (PC3, 8\% of total variance) is characterized by the extent of agricultural versus forest land. Cadastral areas with more agricultural land have higher natality and more children, but also higher unemployment. In settlements with a greater proportion of forest land the first signs of revenues from nature-based tourism are evident, but total revenues in the region have no connection to this phenomenon. Also, this phenomenon is irrelevant to protected areas.

The ratio of men to women (PC4, $6 \%$ of total variance) is irrelevant to protected areas. The area of the national park (PC5, 5\% of total variance) is irrelevant to socioeconomic and demographic variables, apart from the fact that natality in settlements is lower than mortality. This phenomenon is unrelated to revenues in the region. The existence of national nature reserves (NPRs) and nature reserves (PRs) in the region (PC6, 4\% of total variance) is irrelevant to socio-economic and demographic variables. This phenomenon is unrelated to revenues in the region.

The last significant phenomenon (PC7, 3\% of total variance) is characterized by the existence of nature-based tourism and revenues from it. In cadastral areas with a greater proportion of protected areas, revenues from tourism begin to rise. This phenomenon is independent of regional demography. On the basis of all seven phenomena identified, nature protection status is irrelevant to demographic characteristics in the region, and nature conservation has a minimal effect on the socio-economic relations of the population in the region surrounding Poloniny NP.

\section{Discussion}

Some of the trends observed in Poloniny are also seen at the European or regional (Carpathian) levels. In particular, population migration and concentration in cities and larger towns is a global trend of the $21^{\text {st }}$ century. Local demographic trends since World War II have shown a continuous population decrease [12]. These trends have led to land abandonment - a contentious issue within Europe [32]. From a global perspective, emigration and spatial movement of populations is often determined by location and specific social, economic, political, and environmental conditions [42, 30]. Emigration and land 
Table 1. Eigenvectors for the seven most important components.

\begin{tabular}{|c|c|c|c|c|c|c|c|}
\hline & PC 1 & PC 2 & PC 3 & $\mathrm{PC} 4$ & PC 5 & PC 6 & PC 7 \\
\hline Total variance in $\%$ & 42 & 18 & 8 & 6 & 5 & 4 & 3 \\
\hline Area in hectare & -0.523 & -0.818 & 0.146 & -0.054 & -0.154 & 0.083 & -0.026 \\
\hline Area in $\mathrm{m}^{2}$ (GIS) & -0.523 & -0.818 & 0.146 & -0.054 & -0.154 & 0.083 & -0.026 \\
\hline Area - urban area & -0.991 & 0.054 & -0.066 & 0.039 & -0.006 & -0.004 & 0.005 \\
\hline Area - rural area & -0.495 & -0.834 & 0.152 & -0.055 & -0.155 & 0.082 & -0.028 \\
\hline Arable land & -0.861 & 0.074 & 0.183 & 0.038 & 0.310 & -0.188 & -0.067 \\
\hline Garden & -0.615 & -0.329 & 0.116 & 0.230 & 0.225 & 0.050 & 0.240 \\
\hline Grassland & -0.503 & -0.725 & 0.326 & 0.027 & 0.003 & -0.029 & -0.163 \\
\hline Agricultural land & -0.680 & -0.577 & 0.322 & 0.040 & 0.100 & -0.077 & -0.145 \\
\hline Forest land & -0.434 & -0.858 & 0.093 & -0.069 & -0.209 & 0.110 & 0.000 \\
\hline Water areas & -0.412 & -0.812 & 0.280 & -0.087 & -0.141 & 0.178 & 0.020 \\
\hline Build-up areas & -0.989 & -0.099 & -0.009 & -0.022 & -0.078 & 0.069 & -0.005 \\
\hline Other areas & -0.665 & -0.631 & 0.295 & -0.146 & -0.049 & 0.080 & -0.052 \\
\hline Settlements area in $\mathrm{m}^{2}$ & -0.523 & -0.818 & 0.147 & -0.053 & -0.152 & 0.080 & -0.028 \\
\hline Urban rate in $\%$ & -0.705 & 0.613 & 0.226 & 0.057 & -0.046 & 0.035 & 0.065 \\
\hline Rural rate in $\%$ & 0.705 & -0.613 & -0.226 & -0.057 & 0.046 & -0.035 & -0.065 \\
\hline Land use rate in $\%$ & -0.412 & 0.175 & 0.320 & 0.028 & 0.584 & -0.344 & -0.085 \\
\hline Garden rate in $\%$ & 0.110 & 0.457 & 0.558 & 0.319 & -0.197 & 0.212 & 0.242 \\
\hline Grass land rate in $\%$ & 0.213 & 0.434 & 0.711 & 0.249 & -0.296 & 0.055 & -0.176 \\
\hline Agriculture land rate in $\%$ & 0.066 & 0.478 & 0.785 & 0.252 & -0.090 & -0.053 & -0.180 \\
\hline Forest land rate in $\%$ & 0.032 & -0.502 & -0.800 & -0.185 & 0.067 & 0.028 & 0.165 \\
\hline Water area rate in $\%$ & -0.416 & -0.590 & 0.283 & -0.023 & 0.236 & 0.002 & 0.369 \\
\hline Built- up area rate in $\%$ & -0.744 & 0.459 & 0.088 & -0.335 & -0.007 & 0.170 & 0.081 \\
\hline Other area rate in $\%$ & -0.235 & 0.327 & 0.459 & -0.463 & 0.222 & 0.133 & -0.194 \\
\hline National park area & -0.227 & -0.893 & 0.185 & -0.124 & -0.239 & 0.113 & -0.068 \\
\hline Buffer zone area & 0.181 & -0.077 & -0.257 & -0.206 & -0.384 & -0.496 & 0.446 \\
\hline Nature reserves area & -0.038 & -0.449 & -0.083 & 0.323 & 0.065 & 0.584 & 0.447 \\
\hline National NR area & 0.073 & -0.292 & -0.263 & 0.017 & -0.438 & -0.472 & -0.220 \\
\hline National park rate in $\%$ & 0.143 & -0.726 & -0.314 & -0.074 & -0.184 & -0.251 & -0.157 \\
\hline Buffer zone rate in $\%$ & 0.315 & 0.330 & 0.164 & -0.113 & -0.628 & -0.121 & 0.402 \\
\hline Nature reserves rate in $\%$ & 0.096 & -0.122 & -0.211 & 0.361 & 0.144 & 0.507 & 0.550 \\
\hline National NR rate in $\%$ & 0.125 & -0.163 & -0.320 & 0.049 & -0.386 & -0.528 & -0.214 \\
\hline Number of inhabitants & -0.953 & 0.233 & -0.141 & 0.029 & -0.078 & 0.049 & -0.063 \\
\hline Density & -0.926 & 0.349 & -0.103 & 0.032 & -0.056 & 0.013 & -0.039 \\
\hline Male & -0.953 & 0.232 & -0.142 & 0.032 & -0.077 & 0.048 & -0.064 \\
\hline Female & -0.953 & 0.234 & -0.141 & 0.027 & -0.076 & 0.048 & -0.063 \\
\hline Males aged 15-59 & -0.951 & 0.237 & -0.145 & 0.032 & -0.078 & 0.049 & -0.061 \\
\hline Female +55, Male +60 & -0.959 & 0.210 & -0.135 & 0.022 & -0.083 & 0.045 & -0.063 \\
\hline Natality & -0.946 & 0.263 & -0.140 & 0.035 & -0.078 & 0.037 & -0.053 \\
\hline Mortality & -0.961 & 0.224 & -0.113 & 0.055 & -0.086 & -0.001 & 0.013 \\
\hline
\end{tabular}


Table 1. Continuation

\begin{tabular}{|c|c|c|c|c|c|c|c|}
\hline Male rate in $\%$ & -0.056 & -0.262 & -0.356 & 0.671 & 0.319 & -0.105 & -0.085 \\
\hline Female rate in $\%$ & -0.112 & -0.033 & -0.147 & -0.737 & 0.384 & -0.003 & 0.043 \\
\hline Rate in age $0-14$ in $\%$ & -0.334 & 0.024 & 0.659 & 0.094 & 0.161 & -0.159 & 0.004 \\
\hline Female rate $15-54$ in $\%$ & -0.572 & -0.207 & 0.242 & 0.094 & 0.491 & -0.222 & 0.042 \\
\hline Male rate $15-59$ in $\%$ & -0.122 & -0.209 & -0.327 & 0.670 & 0.160 & -0.162 & 0.174 \\
\hline $\mathrm{F}$ rate $55 / \mathrm{M}$ rate 60 in $\%$ & 0.492 & 0.216 & -0.192 & -0.470 & -0.406 & 0.269 & -0.123 \\
\hline Natality rate in $\%$ & -0.188 & 0.198 & 0.630 & 0.342 & -0.335 & -0.214 & 0.158 \\
\hline Mortality rate in \% & 0.331 & 0.268 & 0.176 & 0.537 & -0.571 & 0.083 & 0.098 \\
\hline Unemployed & -0.965 & 0.206 & -0.112 & 0.015 & -0.071 & 0.041 & -0.047 \\
\hline Economic inactive & -0.954 & 0.228 & -0.141 & 0.030 & -0.077 & 0.049 & -0.066 \\
\hline Economic active & -0.951 & 0.238 & -0.144 & 0.029 & -0.080 & 0.047 & -0.062 \\
\hline Higher education & -0.945 & 0.250 & -0.154 & 0.035 & -0.083 & 0.059 & -0.071 \\
\hline Unemployed rate in $\%$ & 0.139 & 0.246 & 0.580 & -0.496 & -0.071 & 0.019 & 0.238 \\
\hline Econ. inactive rate in $\%$ & 0.480 & 0.174 & -0.219 & 0.080 & -0.046 & 0.620 & -0.264 \\
\hline Econ. active rate in $\%$ & -0.480 & -0.174 & 0.219 & -0.080 & 0.046 & -0.620 & 0.264 \\
\hline Higher education rate in $\%$ & -0.685 & -0.336 & -0.009 & 0.303 & 0.278 & -0.099 & 0.028 \\
\hline Forest revenues in $€$ & -0.491 & -0.818 & 0.166 & 0.002 & -0.142 & 0.149 & -0.093 \\
\hline Hunting revenues in $€$ & -0.367 & -0.757 & 0.191 & -0.238 & -0.126 & -0.018 & 0.142 \\
\hline Tax in $€$ & -0.939 & 0.261 & -0.166 & 0.033 & -0.084 & 0.049 & -0.073 \\
\hline Water s. revenues in $€$ & -0.962 & 0.178 & -0.127 & 0.014 & -0.108 & 0.078 & -0.057 \\
\hline Tourism revenues in $€$ & -0.934 & 0.265 & -0.191 & 0.040 & -0.108 & 0.037 & -0.035 \\
\hline Revenues in total in $€$ & -0.928 & -0.298 & -0.013 & 0.017 & -0.147 & 0.123 & -0.091 \\
\hline Forest revenues rate in $\%$ & 0.844 & -0.283 & 0.063 & 0.266 & -0.012 & 0.084 & -0.259 \\
\hline Hunting revenues rate in $\%$ & 0.163 & 0.158 & 0.086 & -0.769 & 0.055 & 0.092 & 0.209 \\
\hline Tax rate in $\%$ & -0.752 & 0.438 & -0.061 & -0.414 & 0.050 & 0.030 & 0.074 \\
\hline Water supply rate in $\%$ & -0.892 & 0.146 & 0.022 & -0.093 & 0.030 & -0.094 & 0.252 \\
\hline Tourism rate in $\%$ & -0.652 & 0.174 & -0.316 & 0.040 & -0.157 & -0.274 & 0.427 \\
\hline
\end{tabular}

abandonment in the Poloniny region are associated with poor technical infrastructure, a marginal location, and deficient employment opportunities [16].

We consider the key to reversing the decline as the involvement of local communities in the economic process: nature-based tourism in rural landscapes, sites of spiritual significance, local sources, craftsmen, volunteers, traditional activities (e.g. honey production), folklore, architecture, spiritual culture (churches provide spiritual value and a sense of identity), and cross-border cooperation. Már [43] from the Szekeler Fruit Association began the Green Social Enterprises project in Romania to safeguard old varieties of fruit trees in a traditional way and produce high added-value products. Within three years, 5,500 local people had benefited from the initiative. Environmental and cultural heritage were combined as a business asset for the benefit of local communities with a vision of generating
$40 \%$ of the annual budget of the owner NGOs by 2020. This would represent 1,000 jobs, 500 local producers involving 1,000 employees. Suitable development does not work without the involvement of local people. In Romania the understanding of forest management in protected areas has also changed. Within 33 days 106,000 people signed a petition calling for all virgin forest to be placed under protection (to stop fragmentation, illegal logging, invasive species, etc.). In Gorgany Nature Reserve and Hutsulchyna NP in Ukraine, tourist activities based on natural heritage and living traditions have been created [44].

Our results, like those of Kušová et al. [45] relating to biosphere reserves in the Czech Republic, show that there is no statistically significant difference between protected areas and their surroundings in terms of objectively measured parameters describing material well-being. Nor do the inhabitants of protected areas feel themselves handi- 
Table 2. Factor scores for individual variables (settlements, villages).

\begin{tabular}{|c|c|c|c|c|c|c|c|}
\hline \multicolumn{8}{|c|}{ Principal components according to settlements } \\
\hline Settlements & PC 1 & PC 2 & PC 3 & PC 4 & PC 5 & PC 6 & PC 7 \\
\hline Osadné & 1.796 & -1.355 & -2.450 & 3.796 & 1.236 & 4.353 & 2.696 \\
\hline Hostovice & 0.330 & -0.688 & 0.974 & 2.389 & 1.896 & 0.108 & -0.352 \\
\hline Stakčín & -6.781 & -13.169 & 3.150 & -1.043 & -1.597 & 1.604 & -0.251 \\
\hline Parihuzovce & 2.951 & 1.127 & -1.773 & 1.792 & 0.705 & 1.759 & -2.033 \\
\hline Runina & 2.398 & -1.077 & -3.831 & 0.264 & -1.451 & -1.595 & 0.222 \\
\hline Pčolinné & -0.012 & -0.778 & 1.478 & 1.290 & 1.658 & -0.372 & -1.311 \\
\hline Zboj & 1.275 & -2.645 & -1.868 & -1.483 & -1.536 & -0.470 & -0.792 \\
\hline Nová Sedlica & 1.690 & -1.396 & -1.953 & 0.656 & -2.982 & -3.198 & -1.021 \\
\hline Topol’a & 1.931 & -0.685 & -1.598 & -0.428 & -0.426 & -0.187 & 0.658 \\
\hline Príslop & 3.248 & 2.623 & -0.128 & 0.057 & -1.313 & 1.943 & -1.068 \\
\hline Ruský Potok & 2.264 & 0.853 & -0.188 & -0.529 & 0.014 & -0.270 & 2.063 \\
\hline Jalová & 2.907 & 5.311 & 6.325 & 2.880 & -4.678 & 0.529 & 0.316 \\
\hline Snina & -21.896 & 5.255 & -2.052 & 0.401 & -0.680 & 0.430 & -0.519 \\
\hline Stakčínska Roztoka & 1.353 & 0.448 & -0.714 & 0.717 & 1.457 & -0.847 & -1.238 \\
\hline Kolbasov & 2.554 & -0.292 & -2.537 & -0.306 & -0.345 & -0.162 & 0.866 \\
\hline Uličské Krivé & 2.130 & 0.167 & -0.360 & -1.057 & -0.279 & -0.438 & -0.489 \\
\hline Kalná Roztoka & 0.626 & -0.204 & 0.295 & 1.118 & 1.799 & -1.572 & -1.026 \\
\hline Ulič & -1.660 & 0.696 & 0.615 & -0.410 & 0.447 & -2.689 & 3.930 \\
\hline Klenová & -0.338 & 0.967 & 3.758 & -0.181 & 3.284 & -1.180 & -1.104 \\
\hline Ruská Volová & 2.117 & 0.433 & -0.076 & -1.129 & 1.157 & 0.198 & -1.128 \\
\hline Brezová & 2.623 & 3.864 & 0.256 & -6.731 & -0.303 & 2.783 & -0.222 \\
\hline Ubl’a & -1.506 & 0.546 & 2.677 & -2.063 & 1.936 & -0.726 & 1.805 \\
\hline
\end{tabular}

capped. For local stakeholders, support for agriculture is essential in such landscapes, favouring farming activities with positive impacts on natural values and biodiversity, as well as local livelihoods and forms of agro-tourism attracting visitors to the region and contributing to its economic growth [16]. Understanding the residents' perspective can facilitate policies that minimize the potential negative impacts of tourism development and maximize its benefits [46].

Settlement structure in the Poloniny region is characterized by small residential settlements of 50-500 inhabitants set in rural landscapes and the towns of Stakčín and Snina. An aging population trend is visible not only in Poloniny, but in general [47], due to changes in health care, values and lifestyle - especially the rural-to-urban migration of young people in search of employment opportunities, where the main economic revenues from forestry and agriculture are insufficient in current circumstances. The birth:death ratio is decreasing in all settlements of the Poloniny region. In some villages more than $50 \%$ of inhabitants are more than 55 years old. The male:female ratio is also decreasing and children under the age of 14 are almost absent. This phenomenon is closely related to unemployment, which is very high.

Based on the concept of ecosystem services [48-50], revenues from forestry represent $77 \%$ of all revenues in the area of Poloniny NP in 2010 [51]. Cadastral areas with more agricultural land have higher natality but also more unemployment. The town of Snina is the centre of socioeconomic development. Population migration to Snina creates positive perspectives for environmental protection, but on the other hand creates pressure on rural areas. Social and environmental problems in cities generate migratory movements from 'large' to 'small' areas, a process characterized by Antrop [52] as the third stage of urban development.

Protected areas in the popular imagination are "places without people' [53]. If the importance of environmental protection is increasingly marginalized in the future, this may lead to the enduring perception among inhabitants of such protection being unnecessary. This is a mistaken perception in contemporary society. In spite of our finding 
that the national park is irrelevant to socio-economic and demographic variables and rural-urban migration, higher population growth on the periphery of protected areas can be seen across ecoregions, countries, and continents, showing their value to local residents [54]. Protected areas may increase economic prospects by increasing access to finance, providing benefits for rural residents. However, if the local system is ineffective or does not exist, there is a negative impact.

Protected areas have a substantial impact on interactions between birth:death dynamics and biotic factors influencing them [55]. For rural residents living in need, the existence of PAs has a negative effect on life. Such people relocate and search for economic resources, infrastructure, and land tenure elsewhere: a massive rural-urban migration is ongoing around the world. According to Sholte and de Groot [56], birth:death ratios are influenced by the strength of the economy, ecosystem services, and infrastructure developed in the region. They identified three basic general models of motivation to move to PAs: frontier engulfment, attraction, and incidental. In the frontier engulfment model, the population at the periphery of a PA based in a still-intact (or remote) area can grow under the influence of an influx of workers in incoming extraction companies (logging, mining, farming). In the attraction model, the population grows as a result of job opportunities in tourism or conservation projects. The third category, incidental mechanisms, includes the influence of random factors (e.g. conflict, disaster). The different models and various stages of frontier engulfment call for different ways to fund and manage PAs that include consideration of their relations to rural and urban populations. PAs have a positive impact on employment in nature-based tourism, relieving pressure on the forestry sector where employment is decreasing, suggesting the importance of alternative employment. Low population density with an absence of local services make it hard to create viable employment opportunities [57]. The market for nature-base tourism is increasing faster than traditional tourism, at a rate of $10-30 \%$ per annum [58]. Tourism development is uneven regional development. Our results support the assumption that villages situated near hiking trails and sites of cultural and natural heritage report higher tourism revenue than those in more remote villages. On the other hand, tourism development also has negative impacts on waste production or sewage outflow from touristic facilities situated in protected areas [59].

For protected areas, challenges are presented by the questions of balancing nature conservation with tourism, integrating community development in conservation, and, more importantly, assuring local people that conserving natural areas is beneficial not only for the State but also for local communities and institutions [60]. The amount of shared taxes for accommodation and municipal waste also depends on the tourism situation in the municipality: more tourism equates to higher tax revenues for the municipality. Revenues from shared taxes for renting land and buildings depend on acreage. Creation and expansion of nature reserves, where shared taxes are not paid, results in decreased tax revenues. This loss could be compensated by developing nature-based tourism. The relationship between tourism, livelihood, and conservation is dynamic and complex [61]. Bezák and Halada [62] provided several socioeconomic and institutional recommendations for future management measures in Poloniny NP: implementation of measures for agro-environmental support, involving local smalland medium-sized enterprises and farmers in agricultural/ environmental support schemes; establishing closer cooperation between local stakeholders, farmers, NGOs, and nature conservation institutions; supporting crossborder cooperation and formation of local information centers; and informing local people via local government about possible support for tourism.

Stakeholder meetings can be a useful way to gain an understanding of stakeholder views [61] and to initiate a debate about the transition of European mountain areas from 'less-favoured' agricultural landscapes to 'highlyvalued' environmental landscapes [63]. The institutional framework for sustainable mountain development has a very strong regional dimension, with numerous active institutions and organizations. The diversity of their structure, legal status, and set of stakeholders demonstrates that a wide array of models is already available [64]. 'Sound environment' and 'well-preserved nature' can be considered as two principal attributes of the territory [45]. Local communities must be able to empower themselves to face the challenges of rural development. Thus, self-reliance is the key to successful empowerment [60]. Therefore, it should be local people who engage in activities and also cooperate with nature conservation bodies to improve and create new economic opportunities founded on naturebased tourism, which should not have an intense (negative) impact on the country and its values.

\section{Acknowledgements}

The authors would like to thank local stakeholders and municipalities in Poloniny NP and the State Nature Conservancy of Slovakia for their useful information and cooperation. We also thank Robin Rigg of Slovak Wildlife Society for linguistic assistance. This research was supported by the Project of Swiss Contribution and State Nature Conservancy of Slovakia (1551/2011), "Development of nature protection and protected areas in the Slovakian Carpathians."

\section{References}

1. BURAL'OVÁ I. 5 rokov od vyhlásenia najvýchodnejšieho parku na Slovensku - NP Poloniny [Five years from the declaration of the easternmost park in Slovakia - NP Poloniny]. Ochrana prírody Slovenska 4, 12, 2002 [In Slovak].

2. BURAL M. Stakčín - prírodné, kultúrno-historické zaujímavosti a turistické možnosti [Stakčín - natural, cultural and historical attractions and tourist opportunities]. Municipality Stakčín. Stakčín. 2009 [In Slovak].

3. BLAŽKOVÁ D., BŘEZINA S. Secondary succession in 
abandoned "poloniny" meadows, Bukovské vrchy Mts., Eastern Carpathians, Slovakia. Thaiszia 13, 159, 2003.

4. BEZÁK P., PETROVIČ F., IZAKOVIČOVÁ Z., MOYZEOVÁ M., HALABUK A. Considering complexity of the landscape in the Poloniny NP (SE Slovakia) through the sustainability assessment: In Multifunctional land use in the rural-urban perspective. Ljubljana. ERN Landscape Tomorrow. 2007.

5. HALADA L', RUŽIČKOVÁ H., DAVID S. Community structure changes after 15 years of grassland management experiment in the Poloniny National Park (NE Slovakia): Succession, management and restoration of dry grasslands. $7^{\text {th }}$ European Dry Grassland Meeting. Smolenice. 2010.

6. JAWORSKI A., KOŁODZIEJ Zb., PORADA K. Structure and dynamics of stands of primeval character in selected areas of the Bieszczady National Park. J. For. Sci. 48 (5), 185, 2002.

7. POLÁK P., BURKOVSKÝ J. Pralesy v Európe [Primeval forests in Europe], In: JASÍK M., POLÁK P., (Eds.) Pralesy Slovenska [Primeval forests in Slovakia]. FSC Slovensko. 69, 2011 [In Slovak].

8. JASÍK M., POLÁK P., (eds.) Pralesy Slovenska [Primeval forests in Slovakia], FSC Slovensko: Banská Bystrica, 228, 2011 [In Slovak].

9. PICHLER V., VOLOŠČUK I. HAMOR F. Karpatské bukové pralesy od roku 2007 svetovým prírodným dedičstvom [Carpathian beech forests since 2007, world heritage]. Enviromagazín 5, 6, 2007 [In Slovak].

10. BEZÁK P., IZAKOVIČOVÁZ., MIKLÓS L., MOYZEOVÁ M., ŠPULEROVÁ J., MOJSES M., KOČICKÝ D., PETROVIČ F., BOLTIŽIAR M., HREŠKO J., et al. Reprezentatívne typy krajiny Slovenska [Representative types of landscape of Slovakia]. Institute of Landscape Ecology Slovak Academy of Sciences: Bratislava, 179, 2010 [In Slovak].

11. IZAKOVIČOVÁ Z. Evaluation of the changes of landscape types of Slovakia. GEOREVIEW 22, 1, 2013.

12. BEZÁK P., MITCHLEY J. Drivers of change in mountain farming in Slovakia: From socialist collectivisation to the Common Agricultural Policy. Regional Environmental Change 14, 1343, 2013. doi: 10.1007/s10113-013-0580-x

13. MICHNIAK D. Vplyv dostupnosti na rozvoj cestovného ruchu vo vybraných regiónoch na Slovensku [Impact of the availability of tourism development in selected regions in Slovakia]. Geogr Cassoviensis 4, 114, 2010 [In Slovak].

14. OLAH B. Land use development and changes, In: KOZOVÁ M., HRNČIAROVÁ T., DRDOŠ J., FINKA M., HREŠKO J., IZAKOVIČOVÁ Z., OŤAHEL' J., RUŽIČKA M., ŽIGRAI F. (eds.) Landscape Ecology in Slovakia. Development, Current State, and Perspectives. Chosen Chapters. Ministry of the Environment of the Slovak Republic. Slovak Association for Landscape Ecology - IALE-SK: Bratislava, 106, 2007.

15. GALLAYI.,GALLAYOVÁZ.Zarastaniepol'nohospodárskej krajiny Slovenska drevinovou vegetáciou. [Overgrowing of agricultural land in Slovakia by woody vegetation.] Geoinformation 8, 18, 2012 [In Slovak].

16. PETROVIČ F., BEZÁK P. Funkcie a konflikty krajiny Národného parku Poloniny [Functions and conflicts of landscape in Poloniny National Park]. Životné prostredie. 40 (5), 267, 2006 [In Slovak].

17. VOLOŠČUK, I. et al. Východné Karpaty. Chránená krajinná oblast' [Eastern Carpatians. Protected landscape area]. Príroda: Bratislava, 334, 1988 [In Slovak].

18. GUZIOVÁ Z., BURAL M. Východné Karpaty/ East Carpathians Biosphere Reserve. In JENÍK J., PRICE M.F., (eds.) Biosphere Reserves on the Crossroads of Central Europe: Czech Republic - Slovak Republic. Empora: Praha, 168, 1994.

19. BURALOVÁ I., NÉMETHOVÁ V. Žijem pod Poloninami, žijem tu rád-Informačný manuál pre pedagógov environmentálnej a regionálnej výchovy [I live under Poloniny, I like live here - The informational guide for educators and regional environmental education]. OZ Čemerica: Stakčín, 83, 2009 [In Slovak].

20. KRAMARIK J. Dva nové národne parky v SR [The Two New National Parks in the Slovak Republic]. Životné Prostredie. 32 (1), 29, 1998 [In Slovak].

21. HALADA, L., GAJDOŠ, P., HREŠKO, J., DAVID, S., GAJDOŠ, P., BUGÁR, G., Successional changes of nonforest vegetation on abandoned areas in the East Carpathians biosphere reserve and consequences on conservation value of the territory. In: GUZIOVÁ, Z. (ed.) International Workshop Changing Natural and Cultural Values in Biosphere Reserves, 24. 2002.

22. MOTTET A., LADET S., COQUÉ N, GIBON A. Agricultural land-use change and its drivers in mountain landscapes: A case study in the Pyrenees. Agriculture, Ecosystems \& Environment 114, 296, 2006. doi:10.1016/j.agee.2005.11.017

23. SITKO I., TROLL M., Timberline Changes in Relation to Summer Farming in the Western Chornohora (Ukrainian Carpathians). Mountain Research and Development 28 (3/4), 263, 2008. doi: http://dx.doi.org/10.1659/mrd.0963

24. KOZAK J. Land Use Change in the Northern Carpathians. Alpine space - man \& environ. 7, 93, 2009.

25. GRIFFITHS P., MÜLLER D., KUEMMERLE T., HOSTERT P. Agricultural land change in the Carpathian ecoregion after the breakdown of socialism and expansion of the European Union. Environ Res Lett. 8, 1, 2013.

26. TURNOCK, D. Ecoregion-based conservation in the Carpathians and the land-use implications. Land Use Policy 19, 47, 2002. doi:10.1016/S0264-8377(01)00039-4

27. KOZAK J. Forest cover change in the Western Carpathians in the past 180 years: A case study in the Orawa region in Poland. Moun. Res. Dev. 23, 369, 2003.

28. KOZAK J., ESTREGUIL C., TROLL M. Forest cover changes in the northern Carpathians in the 20th century: A slow transition. J. Land Use Sci. 2, 127, 2007. doi: 10.1080/17474230701218244

29. KUEMMERLE T., CHASKOVSKYY O., KNORN J., RADELOFF V.C., KRUHLOV I., KEETON W.S., HOSTERT P. Forest cover change and illegal logging in the Ukrainian Carpathians in the transition period from 1988 to 2007. Remote Sen. Environ. 113, 1194, 2009. doi: 10.1016/j.rse.2009.02.006

30. MACDONALD D., CRABTREE J.R., WIESINGER G., DAX T., STAMOU N., FLEURY P., LAZPITA J.G., GIBON A. Agricultural abandonment in mountain areas of Europe: Environmental consequences and policy response. J. Environ. Manag. 59, 47, 2000. doi:10.1006/jema.1999.0335

31. GELLRICH M., BAUR P., ZIMMERMANN N.E. Natural forest regrowth as a proxy variable for agricultural land abandonment in the Swiss mountains: A spatial statistical model based on geophysical and socio-economic variables. Environ Model Assess. 12, 269, 2007. doi: 10.1007/s10666006-9062-6

32. RENWICK A., JANSSON T., VERBURG P. H., REVOREDO-GIHA C., BRITZ W., GOCHT A., MCCRACKEN D. Policy reform and agricultural land abandonment in the EU. Land Use Policy 30 (1), 446, 2013. doi: 10.1016/j.landusepol.2012.04.005

33. KUEMMERLE T., HOSTERT P., RADELOFF V.C, PERZANOWSKI K., KRUHLOV I. Post-socialist forest distur- 
bance in the Carpathian border region of Poland, Slovakia, and Ukraine. Ecological Applications 17, 1279, 2007. doi: 10.1890/06-1661.1

34. UNCED United Nations Conference on Environment and Development, Declaration. United Nations, New York. 1992.

35. HRNČIAROVÁ T., HUBA M., IRA V., KLINEC I., KOVÁČ M., KOZOVÁ M., MEDERLY P., SOKOLOVSKÝ L., ŠVIHLOVÁ D, et al. Národná stratégia trvalo udržatel’ného rozvoja Slovenskej republiky [National Strategy for Sustainable Development of the Slovak Republic]. REC Slovensko: Bratislava, pp. 309, 2000. [In Slovak].

36. LAND REGISTRY PORTAL OF SLOVAK REPUBLIC Land Registry portal of Slovak Republic. http://www. katasterportal.sk/. Accessed 15 February 2013.

37. STATISTICAL OFFICE OF SLOVAK REPUBLIC Censuses of population and housing in the year 2011. http://www. statistics.sk. Accessed 15 February 2013.

38. SLOVAK HERITAGE OFFICE OF SLOVAK REPUBLIC National cultural monuments. http://www.pamiatky.sk/po/ po. Accessed 15 February 2013.

39. SLOVAK ENVIRONMENTAL AGENCY State List of specially protected natural environment of the Slovak Republic. http://www.uzemia.enviroportal.sk/. Accessed 15 February 2013.

40. FOREST GEOGRAPHIC INFORMATICS SYSTEM LGIS. National Forest Centre. Zvolen. http://gis.nlcsk.org/lgis/. Accessed 15 February 2013

41. BUČKO J. Pol'ovnícka databáza [Database of hunting]. National Forest Centre: Zvolen. 2011 [In Slovak].

42. BALDOCK D., BEAUFOY G., BROUWER F., GODESCHALK F. Farming at the margins: Abandonment or redeployment of agricultural land in Europe. Institute for European and Environmental Policy and Agricultural Economics Research Institute: London, The Hague, 1996.

43. MÁR I. Sustainable development opportunities in and around protected areas with a focus on stakeholder support for protected area management and financing. $2^{\text {nd }}$ Conference of the Carpathian network of protected areas. 23-26 April, Tatranská Javorina, Slovakia, 2013.

44. SLOBODYAN O. Sustainable development opportunities in and around protected areas with a focus on stakeholder support for protected area management and financing. 2nd Conference of the Carpathian Network of Protected Areas. 23-26 April, Tatranská Javorina, Slovakia, 2013.

45. KUŠOVÁ D., TĚŠITEL J., MAŤEJKA K., BARTOŠ M. Biosphere reserves - An attempt to form sustainable landscapes: A case study of three biosphere reserves in the Czech Republic. Landscape Urban Plan. 84, 38, 2008. doi: 10.1016/j.landurbplan.2007.06.006

46. STYLIDIS D., BIRAN A., SIT J., SZIVAS E.M. Residents' support for tourism development: The role of residents' place image and perceived tourism impacts. Tourism Management 45, 260. 2014.

47. JENÍČEK V., FOLTÝN J. Globální problémy a svetová ekonomika [Global problems and world economy]. 1th ed; Praha. C. H. Beck: Praha. Czech. 2003 [In Czech].

48. WESTMAN W. How much are nature's services worth? Science 197, 960, 1977.

49. PAGIOLA S., VON RITTER K., BISHOP J. How much is the ecosystem worth? Assessing the economic value of conservation. The International Bank for Reconstruction/ The World Bank. IUCN: Washington, 2004.
50. PAGIOLA S., PLATAIS G. Payments for Environmental Services: From Theory to Practice. World Bank: Washington, 2007.

51. JANIGA M., MARKULJAKOVÁ K., MAHÚT O., POGÁNYOVÁ P., KOHÚTOVÁ Z., ŠULAVÍK J., BOHÁČOVÁ A., HERIAN N., IVANIČOVÁ Z., VESELSKÁ M., et al. Revenues of the stakeholders in the national parks and landscape protection areas of the Slovak Republic. Oecologia Montana 21 (2), 1, 2012 [In Slovak].

52. ANTROP M. Landscape change and the urbanization process in Europe. Landscape and Urban Planning 67, 9, 2004. doi:10.1016/S0169-2046(03)00026-4

53. WEST P., IGOE J., BROCKINGTON D. Parks and Peoples: The Social Impact of Protected Areas. Annu. Rev. Anthropol. 35, 251, 2006. doi: 10.1146/annurev. anthro.35.081705.123308

54. WITTEMYER G., ELSEN P., T. BEAN W., COLEMAN A., BURTON O., BRASHARES J.S. Accelerated Human Population Growth at Protected Area Edges. Science 321, 123, 2008

55. JOPPA L. Population change in and around Protected Areas. J. Ecol. Anthropol. 15 (1), 58, 2012. doi: 10.5038/21624593.15.1.4

56. SHOLTE P., DE GROOT W. T. From debate to insight: Three models of immigration to protected areas. Conserv. Biol. 24 (2), 630, 2009. doi: 10.1111/j.1523-1739.2009.01314.x

57. LUNDMARK L.J.T., FREDMAN P., SANDELL K. National parks and protected areas and the role for employment in tourism and forest sectors: A Swedish case. Ecol Soc. 15 (1), 19, 2010.

58. NEVIN O.T., SWAIN P., CONVERY I. Nature Tourism: Do bears create a sense of place? In Making Sense of Place: Multidisciplinary Perspectives. The Boydell Press: Woodbridge, 276, 2012.

59. KACZOR G., BERGEL T., BUGAJSKI P., PIJANOWSKI J. Aspects of Sewage Disposal from Tourist Facilities in National Parks and Other Protected Areas. Pol. J. Environ. Stud., 24 107, 2015. doi: 10.15244/pjoes/28355

60. NEPAL S.K. Sustainable tourism, protected areas and livehood needs of local communities in developing countries. Int. J. Sust. Dev. World 4, 123, 1997. doi: 10.1080/13504509709469948

61. IMRAN S., ALAM K., BEAUMONT N. Environmental orientations and environmental behaviour: Perceptions of protected area tourism stakeholders, Tourism Management, 40, 290, 2014. doi:10.1016/j.tourman.2013.07.003

62. BEZÁK P., HALADA L'. Sustainable management recommendations to reduce the loss of agricultural biodiversity in the mountain regions of NE Slovakia. Mountain Research and Development 30 (3), 192, 2010.

63. SOLIVA R., RØNNINGEN K., BELLA I., BEZÁK P., COOPER T., FLØ B. E., MARTY P., POTTER C. Envisioning upland futures: Stakeholder responses to scenarios for Europe's mountain landscapes. J. Rural. Stud. 24, 56, 2008. doi: 10.1016/j.jrurstud.2007.04.001

64. KOHLER T., PRATT J., DEBARBIEUX B., BALSIGER J., RUDAZ G., MASELLI D. (eds.) Sustainable Mountain Development, Green Economy and Institutions: From Rio 1992 to Rio 2012 and beyond. Centre for Development and Environment, Swiss Agency for Development and Cooperation, University of Geneva and Geographica Bernensia, Bern, 144, 2015. 